Revista Brasileira de Farmacognosia Brazilian Journal of Pharmacognosy 21(3): 382-391, May./Jun. 2011

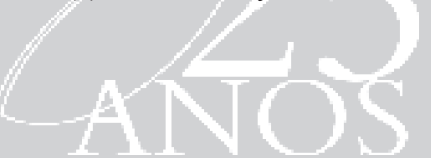

Article

Received 13 Oct 2010

Accepted 3 Nov 2010

Available online 1 Apr 2011

Keywords:

Ethnobotany

intracultural variation

traditional botanical knowledge

Caatinga

ISSN 0102-695X

doi: $10.1590 / \mathrm{S} 0102-695 \times 2011005000054$

\section{Dynamics of traditional knowledge of medicinal plants in a rural community in the Brazilian semi-arid region}

\author{
Flávia dos Santos Silva, ${ }^{1}$ Marcelo A. Ramos, ${ }^{1}$ Natalia Hanazaki, ${ }^{2}$ \\ Ulysses P. de Albuquerque ${ }^{*}, 1$
}

\author{
${ }^{1}$ Departamento de Biologia, Área de Botânica, Laboratório de Etnobotânica Aplicada, \\ Universidade Federal Rural de Pernambuco, Brazil, \\ ${ }^{2}$ Departamento de Ecologia e Zoologia, Laboratório de Etnobotânica e Ecologia \\ Humana,Universidade Federal de Santa Catarina, Brazil.
}

\begin{abstract}
Human beings have accumulated rich experience with natural resources over time, but such knowledge can be strongly influenced by several factors, such as age, sex and occupation. This study focuses on the influence of these factors on knowledge of medicinal plants in a rural community in northeastern Brazil. Data were collected through semi-structured interviews with 102 people, with the number of plants and uses cited studied for quantitative analysis. Through this research, it was possible to show that the social variables studied (age, sex and informants occupation) have contributed to the formation of different patterns of knowledge regarding medicinal resources. The results indicate that awareness of this dynamic is necessary for the proper implementation of projects where the goal is the sustainable use of natural resources (because it indicates the different levels of knowledge within a community), for studies intended to discover new drugs (because it indicates the peculiarities of certain groups), and for biodiversity conservation strategies.
\end{abstract}

\section{Introduction}

Throughout history, mankind has always tried to develop strategies for properly managing and using natural resources to meet his daily needs. This is especially true with regard to the use of plant resources that are so strikingly present in many aspects of peoples' lives in different cultures in the world (Albuquerque et al., 2005; Case et al., 2005). Accordingly, experience gained over years of contact with the environment and different social groups has now become an element of great interest, because cultural factors may both contribute to the diversity and richness of knowledge of plants through transmission between groups (Bain, 1993; Estomba et al., 2006). In addition, the importance of social aspects that are most commonly investigated in the literature are highlighted here. These include age, gender and occupation, and they exert an important influence on the knowledge accumulated by an individual, which affect the individual's knowledge of the use plants (Figueiredo et al., 1993; Hanazaki et al., 2000; Monteiro et al., 2006a; Ayantude et al., 2008).

Quinlan \& Quinlan (2007), researching medicinal plants in the Dominican Republic, found that people who are involved in business activities and have less contact with plant resources run the risk of losing this sort of knowledge and losing familiarity with traditional medical practices. In some social contexts, the local knowledge may be strongly influenced by gender, which affects the behavior and occupation of individuals. Regarding age, Quinlan \& Quinlan (2007) found that older people are less affected by external influences than younger people and that in many cases; they are the experts and protectors of local knowledge.

In Brazil, there are few studies that address the influence of social and economic factors on local knowledge, especially in the semi-arid region, although knowledge of plants in this region is very rich. Albuquerque et al. (2007) recorded a total diversity of 389 medical species in the "caatinga" (semi-arid vegetation region). In this context, this study aimed to contribute information on the use and exploitation of medicinal plants in the semi-arid region of Pernambuco (northeast Brazil), and sought to reveal factors that may disrupt knowledge of medicinal plants in a rural community. Toward this end, knowledge of medicinal plants as related to age was tested, with differences sought based on gender and occupation type.

\section{Materials and methods}

\section{Study area}


The study was conducted in the Carão community, which is located in the Altinho municipality of the state of Pernambuco in northeast Brazil. The city of Altinho is located $162 \mathrm{~km}$ from the state capital, Recife (Condepe/Fidem, 2001). The climate is hot and semi-arid; it is type BSH according to Köppen's classification, with an average annual temperature of $23.1{ }^{\circ} \mathrm{C}$ (ITEP/Lamepe, 2007) and vegetation formed by Caatinga (semiarid vegetation).

The Carão community is located in a rural area $16 \mathrm{~km}$ far from downtown Altinho (S8 29 '23"W and $\left.36^{\circ} 03^{\prime} 34^{\prime \prime}\right)$. Carão has a population of 189 people living in 61 homes. This community presents interesting characteristics that contributed to its selection as the study area; for instance, it is distant from the urban center, and there is a slope with natural vegetation in its vicinity from which residents extract plant resources to supply their needs. Some of the inhabitants perform subsistence activities in agriculture, including the cultivation of maize, beans and palms (Opuntia ficusindica (L.) Mill., Cactaceae). Cattle and goats are also raised.

In this community, there is a small health center responsible for primary healthcare; patients with more severe health issues are directed to the hospital in Altinho. The health center has a doctor who performs consultations once a month and a nurse who works weekly, in addition to two healthcare workers who carry out in-home visits to residents and distribute some medicines and pharmaceuticals for free. There is an elementary school in the community, but students who continue on to middle and high school must move to Altinho city. The community exhibits poorly developed commercial infrastructure (only a butcher shop and bars are present in the community) and has a public telephone, electricity, and public transport to facilitate access to the downtown area. There are no paved streets, nor is there a water distribution or sewer system (Alencar et al., 2009, 2010; Araújo et al., 2008; Lins-Neto et al., 2010; Santos et al., 2009).

\section{Data collection}

All community members were invited to a meeting where the research objectives were explained. Following this meeting, residents were invited to participate in the study, and if they accepted, they were asked to sign the Free and Informed Consent Term (FICT). Only those individuals over eighteen years of age were included in the study, totaling 112 people, of which eight individuals gave up and two refused to participate in the study. The final result was a sample of 102 interviewed people (67 women and 35 men).

The study was conducted from August 2006 to September 2008. The data collection consisted of interviews divided into two parts: in the first, a socioeconomic questionnaire was applied to register the names of the informants, their age, their profession and the amount of time they have been employed in this capacity, their educational background, the number of people living in their home, their duration of residence at that location and their place of birth. The second part of the study began with semi-structured interviews (Albuquerque et al., 2008), with the following question asked first: "What are the plants that you know and/ or use for any purpose?" All of the uses of each plant cited were registered at this juncture, and in the case of those cited as medical, the informants were also asked which parts of the plant cited were used, its indications, the collection site and the manner of preparing it. Subsequently, we would organize a guided tour, "supporting and validating the names of the plants mentioned in the interviews" (Albuquerque et al., 2008) and adding to the list of plants by means of visual examination and the collection of plant material for taxonomic identification purposes. Based on the interviews, a database was built that selected for the purposes of this study only the plants that had medical indications as mentioned by the informants.

The plants cited in the interviews were collected and subsequently herborized and identified via comparison with the herbarium material, consultation with experts and specialist literature. The material identified was incorporated into the collection of Herbarium Professor Vasconcelos from the Federal Rural University of Pernambuco in the case of duplicates, while the plants with only one specimen were incorporated into that of Herbarium Professor Geraldo Mariz, Federal University of Pernambuco.

\section{Data Analysis}

Tests were performed based on the number of cited ethnospecies (folk names given to one or several species) and their therapeutic indications for human use. All names assigned to a single botanical species were considered to accommodate the wide variety of popular names in the region studied. To assess the relationship between the number of plants mentioned by each informant and the informants' age, the Spearman correlation test was utilized. The nonparametric Kruskal-Wallis test was used to check for significant differences in the knowledge of individuals regarding medicinal plants and the number of citations regarding medicinal uses. For this purpose, three variables were taken into account: gender, occupation and age. For all of these tests, the BioEstat 5.0 (Ayres et al., 2007) software was used.

The age of the informants in the community ranged from eighteen to ninety years, and they were 
grouped into ten year age groups. An analysis of variance for age was conducted, with men and women distributed into age classes. For the analysis of the women, one female informant belonging to 59-68 year old age group was excluded from the sample because of the high number of ethnospecies and therapeutic indications mentioned by the individual (95 and 86 respectively) compared to the number mentioned by the other informants (Table 1). As a result of this difference, her presence in the sample could have inappropriately influenced the results. The same occurred among the men, with an informant withdrawn from each of the 39-48 and 69-78 age groups. Comparisons of the males based on age were only performed for age groups 39-48, 49-58, 59-68 and 69-78 due to the low number of people in the other sample groups (Table 1). The differences between men and women for the same variables (the number of therapeutic indications and plants) were also analyzed.

In terms of occupation, informants were grouped into two categories: non-farmers and farmers. In the non-farmer category, all people not performing activities related to agriculture were grouped together (for example, health workers, midwives, traders, general service assistants, dressmakers, hairdressers, housemaids, students, teachers and mechanics), while all those who once participated in or currently participate in this activity were included in the farmer group. These variables were selected because agriculture is a predominant activity in the study area, and people who work in this arena maintain greater contact with plant resources in the region as compared to non-farmers.

Additionally, we evaluated knowledge based on the mention of particular species exclusively in particular age groups. Toward this end, species that were mentioned by individuals in all age groups and those whose mention was unique to any group were identified among the informants at large and by gender. The number of botanical species was the variable chosen for this analysis because a botanical species can have different local names. The purpose was to check whether the knowledge of medicinal species is shared by most of the informants or whether it is restricted to certain age groups.

\section{Results}

\section{Diversity of medicinal plants cited by informants}

A total of 220 therapeutic indications were cited for 231 ethnospecies. Of the ethnospecies cited, 93\% were identified; some species did not occur in the community but were rather acquired in trade or in adjacent communities. It was possible to identify 212 ethnospecies distributed among 158 taxa (136 identifications on the species level and 22 at the genus level).

\section{Age influence on the local knowledge}

The number of plants mentioned by each informant was shown to be related with age; although this relationship is considered weak ( $\mathrm{rs}=0.39$, $p<0.0001$ ), it is still possible to say that the greater the age, the greater the number of plants known.

In comparing the means of ethnospecies and uses cited by individuals in the different age groups (Table 1), significant differences were observed between informants belonging to the 18-28 age group and almost all other age classes except for the 29-38 age group and the oldest class of informants (79-90), indicating that the diversity of ethnospecies and uses cited among the younger people are on average lower and similar between the amount cited by the elderly. This may be the result of limited experience or even little contact with community members who could have shared their knowledge of plant resources.

Some age groups were only different in the number of ethnospecies cited, like the 29-38 group as compared with the 59-68 group "59-68" $(\mathrm{H}=5.02$, $p<0.025)$ and the $69-78$ group $(\mathrm{H}=6.38, p=0.115)$; the same is also true for the 18-28 group versus the 49-58 group $(\mathrm{H}=4.43, \mathrm{p}=0.035)$. The informants belonging to the latter group were more knowledgeable about medicinal plants and their uses (Table 1), but it should be noted that this number may have been influenced by the presence in the sample of an informant who named 95 ethnospecies, 51 more than the average total quoted by the informants in this group.

When analyzing the age influence and the gender, we observed different patterns of distribution of knowledge for men and women (Table 1). On average, women had uniform knowledge of the citation of ethnospecies and uses. For women in particular, there were significant differences between the 18-28 age group and all the other groups except for the last age group (79-90 years), indicating once again that among the youngest (18 to 28 years), the amount of knowledge is distinct and similar only to the quantity of knowledge presented by elderly people in the community. The latter possibly presents a reduction in knowledge due to memory problems and forgetfulness, which are common to people in higher age groups. The women who on average reported more plants and medicinal uses were those aged between 69-78 years (Table 1). However, the class that most contributed to the richness of the pool of ethnospecies was the 59-68 group (Figure 1). 


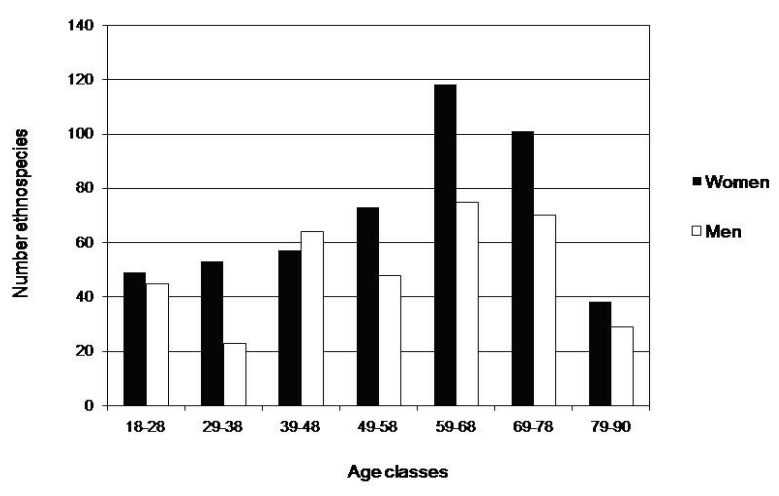

Figure 1. Distribution of knowledge of medicinal plants among men and women of different age groups in the Carão community, Altinho (Pernambuco, Northeast Brazil).

There were no significant differences between the knowledge of men in different age groups on ethnospecies and medical uses, showing that knowledge about medicinal plants of this gender seems to be more uniform than that among women. Men between 59 and 68 years cited a greater richness of ethnospecies than those from other classes (Figure 1). However, curiously, the youngest men (18-28) mentioned more medicinal plants and noted more uses for them than did the oldest ones (59-68) (Table 1), although the information provided by this youngest class came from only three informants, which is a much lower number than the number of people in the other groups.

For all of the age groups studied, there were some plants that were mentioned exclusively by one group (Table 1), with a total richness of 34 species in this situation. The groups that mentioned plants not discussed by other groups were the ranges 39-48, 49-58 and 69-78 years. Informants from the youngest age group (18-28), as well as those from the oldest one (79-90), cited a lower abundance of exclusive species (Table 1), repeating the same pattern recorded in evaluating the total number of ethnospecies cited by men and women. However, it should be noted that there was no significant relationship between the total diversity of plants mentioned in a class and the diversity of exclusive species occurring in it $(\mathrm{rs}=0.6, p>0.1)$. In general, the older people, with the exception of very oldest people, also had greater knowledge concerning the existence of exclusive plants.

A total of twenty species were mentioned by all age groups, while eighteen of them were more frequently cited and are presented in Table 2 . For most of these species, uses are related to the conditions of undefined pain and disorders in the digestive and respiratory systems. These types of problems are probably highlighted because they are the ones that most commonly affect people in the community.

\section{Influence of gender on local knowledge}

Knowledge of the practices and richness of the ethnospecies cited did not differ between men and women $(\mathrm{H}=1.02, p=3.119$ and $\mathrm{H}=1.24, p=2.66$, respectively). Women cited $209 \quad(\chi=14.23 \pm 9.04)$ and men $158 \quad(\chi=16.14 \pm 9.7)$ ethnospecies, while concerning uses, they mentioned $183(\chi=11.6 \pm 69)$ and $123(\chi=12.9 \pm 8.2)$, respectively. Regarding the number of species mentioned, men cited a total of 102, with eleven species uniquely mentioned by them, while women cited 118 species of medicinal plants, with the mention of 27 species exclusive to women (Table 3). Concerning the uses of the plants mentioned exclusively by either by men and women, we can note that they were not intended to treat gender-specific diseases as we expected (Table 3).

Table 1. Analysis of variance of the knowledge of medicinal plants by age and gender groups in the Carão community, Altinho (Pernambuco, Northeast Brazil).

\begin{tabular}{|c|c|c|c|c|c|c|c|c|c|c|c|}
\hline \multirow{3}{*}{$\begin{array}{l}\text { Age } \\
\text { groups }\end{array}$} & \multirow{3}{*}{ NI } & \multirow{3}{*}{$\begin{array}{c}\begin{array}{c}\text { General } \\
\text { average } \\
\text { number of } \\
\text { ethnospecies }\end{array} \\
\chi \pm \mathrm{SD}^{*}\end{array}$} & \multirow{3}{*}{$\begin{array}{c}\begin{array}{c}\text { General } \\
\text { Average } \\
\text { number of } \\
\text { uses }\end{array} \\
\chi \pm \mathrm{SD}^{*}\end{array}$} & \multirow{3}{*}{ NMI } & \multirow{3}{*}{ NFI } & \multicolumn{2}{|c|}{$\begin{array}{c}\text { Average number of cited } \\
\text { uses }\end{array}$} & \multicolumn{2}{|c|}{$\begin{array}{l}\text { Average number of cited } \\
\text { ethnospecies }\end{array}$} & \multirow{3}{*}{$\begin{array}{c}\text { Total } \\
\text { diversity } \\
\text { of cited } \\
\text { species }\end{array}$} & \multirow{3}{*}{$\begin{array}{c}\text { Number } \\
\text { of } \\
\text { exclusive } \\
\text { species }\end{array}$} \\
\hline & & & & & & Male & Female & Male & Female & & \\
\hline & & & & & & $\chi \pm \mathrm{SD}^{*}$ & $\chi \pm \mathrm{SD}^{*}$ & $\chi \pm \mathrm{SD}^{*}$ & $\chi \pm \mathrm{SD}^{*}$ & & \\
\hline $18-28$ & 19 & $9.74 \pm 7.31^{\mathrm{a}}$ & $7.58 \pm 4.69^{\mathrm{a}}$ & 3 & 16 & $* * 15 \pm 3.6$ & $6.19 \pm 3.4^{\mathrm{a}}$ & $* * 20.33 \pm 12.1$ & $7.75 \pm 4.2^{\mathrm{a}}$ & 61 & 3 \\
\hline $29-38$ & 11 & $11.82 \pm 5.87^{\mathrm{ac}}$ & $10.64 \pm 3.96^{\mathrm{ab}}$ & 3 & 8 & $* * 9.0 \pm 2.0$ & $11.25 \pm 4.4^{\mathrm{b}}$ & $* * 9.0 \pm 1.0$ & $12.87 \pm 6.6^{\mathrm{b}}$ & 56 & 3 \\
\hline $39-48$ & 19 & $14.9 \pm 8.61^{\mathrm{bc}}$ & $12.9 \pm 9.23^{\mathrm{b}}$ & 7 & 11 & $7.43 \pm 3.4^{\mathrm{a}}$ & $13.73 \pm 6.3^{b}$ & $10.57 \pm 5.7^{\mathrm{a}}$ & $15.64 \pm 7.2^{\mathrm{b}}$ & 77 & 7 \\
\hline $49-58$ & 15 & $16.14 \pm 9.98^{\mathrm{bc}}$ & $11.6 \pm 6.01^{\mathrm{ab}}$ & 5 & 10 & $11.2 \pm 6.7^{\mathrm{a}}$ & $11.8 \pm 6.0^{\mathrm{b}}$ & $13.8 \pm 10.8^{\mathrm{a}}$ & $17.3 \pm 9.9^{\mathrm{b}}$ & 89 & 7 \\
\hline $59-68$ & 17 & $22.0 \pm 19.99^{b}$ & $17.41 \pm 18.0^{\mathrm{b}}$ & 9 & 7 & $14.44 \pm 7.0^{\mathrm{a}}$ & $9.95 \pm 3.1^{\mathrm{b}}$ & $18.33 \pm 8.0^{\mathrm{a}}$ & $16.28 \pm 5.8^{b}$ & 67 & 2 \\
\hline $69-78$ & 14 & $21.15 \pm 13.62^{b}$ & $16.14 \pm 11.13^{\mathrm{b}}$ & 4 & 9 & $11.0 \pm 2.4^{\mathrm{a}}$ & $16.44 \pm 12.1^{\mathrm{b}}$ & $14.25 \pm 2.1^{\mathrm{a}}$ & $21.67 \pm 14.5^{\mathrm{b}}$ & 81 & 8 \\
\hline $79-90$ & 7 & $12.72 \pm 4.2^{\mathrm{ab}}$ & $10.0 \pm 4.97^{\mathrm{ab}}$ & 2 & 5 & $7.0 * *$ & $9.8 \pm 6.0^{\mathrm{ab}}$ & $15.5^{* *}$ & $11.6 \pm 4.6^{\mathrm{ab}}$ & 48 & 4 \\
\hline
\end{tabular}

NI-Number of informants, NMI-Number of male informants, NFI-Number of female informants

*Equal letters arranged in the same column indicate no significant differences from the data using the Kruskal-Wallis test $(p<0.05)$.

**Sample size was not sufficient for statistical analysis. 
Table 2. Species of medicinal plants mentioned by all age groups in the Carão community, Altinho (Pernambuco, Northeast Brazil).

\begin{tabular}{|c|c|c|c|}
\hline Species & Local name & Citations & Therapeutic indications \\
\hline Myracrodruon urundeuva Allemão & aroeira, aroeira-branca & 50 & $\begin{array}{l}\text { Uterine and renal diseases, anti-inflammatory, cancer, healing, } \\
\text { ovarian cysts, itching, grippe, injury, toothache and legs, } \\
\text { expectorant, gastritis, ulcers, grippe, infection, urinary infection, } \\
\text { inflammation, tooth inflammation, inflammation in women, } \\
\text { inflammation in the throat and the uterus, leg swelling, liver } \\
\text { problems, prostate, burns, cough, worms }\end{array}$ \\
\hline Cymbopogon citratus (DC.) Stapf & capim-santo & 40 & $\begin{array}{l}\text { AVC, calming, colic, congestion, diabetes, diarrhea, stomach pain, } \\
\text { fever, gas, insomnia }\end{array}$ \\
\hline $\begin{array}{l}\text { Amburana cearensis (Allemão) } \\
\text { A.C. Sm. }\end{array}$ & $\begin{array}{l}\text { cumaru, imburana-açu, } \\
\text { imburana-de-cheiro }\end{array}$ & 39 & $\begin{array}{l}\text { Uterine disorders, pain, bronchitis, scarring, congestion, grippe, } \\
\text { decongestants, pain, expectorant, dry throat, grippe, infection, } \\
\text { inflammation, indigestion, bad breath, pneumonia, hoarseness, } \\
\text { sinusitis, dizziness, cough }\end{array}$ \\
\hline
\end{tabular}

Plectranthus barbatus Andrews

Lippia alba (Mill.) N.E. Br. ex Britton \& P. Wilson

Jatropha mollissima (Pohl) Baill.

Caesalpinia pyramidalis Tul.

Anacardium occidentale L.

Plectranthus amboinicus (Lour.) Spreng.

Caesalpinia ferrea Mart.

Psidium guajava L.

Chenopodium ambrosioides L.

Aloe vera (L.) Burm. f.

Ziziphus joazeiro Mart.

Maytenus rigida Mart.

Anadenanthera colubrina (Vell.) Brenan

Croton rhamnifolius Willd.

Eucalyptus globulus Labill.

Spondias tuberosa Arruda

Erythrina velutina Willd. hortelã-de-lajedo, hortelãmiúda

cidreira

pião, pião-bravo

catingueira, catingueirarasteira

caju, caju-roxo, cajubranco

hortelã-grande

jucá

boiaba, goiaba-branca

mastruz

babosa, erva-babosa

juá, juazeiro

bom-nome

angico, angico-de-caroço, angico-branco, angicode-espinho, angico-liso, angico-preto

velame, velame-branco, velame-bravo

eucalipto umbu

mulungu
Amoebiasis, analgesic, colic, congestion, stomachache, headache, toothache, empachamento, expectorant, fever, gastritis, giardiasis, grippe, cough, hemorrhoids, lung problems, dizziness, tuberculosis

36 Sedative, insomnia, swollen belly, bad digestion, colic, diarrhea, congestion, bellyache and headache, migraine, fever, gas, grippe, cough, dizziness, worms

36 Healing, toothache, injury, gastritis, ulcer, warts from snake bite, insect bite, taking spots on the skin

36 Grippe, expectorant, cough, congestion, diarrhea, bloody feces, gastritis, hepatitis, sexual impotence, urinary infections, rheumatism

36 Uterine disorders, ulcers, anti-inflammatory, healing, ovarian cysts, inflamed tooth, diabetes, grippe, inflammation, throat inflammation, infection, pain

32 Bad digestion, laxative, pain in general, analgesic, congestion, cough, expectorant, grippe, lung problems, headache and earache

30 Uterine disorders, kidney disorders, pulmonary disorders, expectorant, asthma, calming, congestion, diarrhea, bellyache, worms, injury, gastritis, cough, grippe, bleeding, liver poisoning, sanative

28 Itching in the head, congestion, diarrhea, colics, congestion, bloody feces

26 Anti-helminths, congestion, restorative, gastritis, worms, hemorrhoids, grippe, bronchitis, pneumonia, cough, expectorant

26 Dandruff, hair loss, injury, scarring, itching, cancer, inflammation, stomach problems, worms, hemorrhoids, amoebiasis

25 Dandruff, anti-inflammatory, expectorant, healing, constipation, bellyache, grippe, cough, tuberculosis, insomnia, worms

25 Renal and urinary disorders, kidney stones, constipation, injury, vaginal infections, gastritis, hematoma, infection, renal and urethral inflammation, liver and kidney problems

25 Uterine and renal diseases, analgesic, anti-inflammatory, bronchitis, grippe, cough, expectorant, tuberculosis, wounds, itching, worms

22 To make the blood thinner, allergy, anemia, cough, swollen belly, scarring, itching, wounds, diarrhea, pain in the spine, cracks in the feet, new blood

20 Pulmonary diseases, asthma, headache, fever, weakness, grippe

20 Uterine disorders, ulcers, cholesterol, congestion, inflamed wounds, diarrhea, bellyache, empachamento of the belly, inflammation, inflammation in the throat and tooth

18 Kidney disorders, cramps, urinary incontinence, insomnia, infection, bladder inflammation, constipation, soothing 
Most of the uses of species cited exclusively by women had to do with the respiratory (6) and digestive (6) tracts (Table 3 ). This may be because the diseases linked to these systems are more common in families, especially among children, and thus women should be familiar with a greater variety of plants used for such purposes. For men, the indications cited were related to problems with various bod systems.

\section{Influence of occupation type on local knowledge}

Of the 102 informants interviewed, 77 worked in agriculture, while 25 did not but are instead occupied with activities. Comparing the number of known

Table 3. Medicinal plants mentioned exclusively by men or women from the Carão community, Altinho, Pernambuco, Brazil.

\begin{tabular}{|c|c|c|c|}
\hline Species & Local name & Therapeutic indications & $\begin{array}{c}\text { Exclusive } \\
\text { citation }\end{array}$ \\
\hline Abelmoschus esculentus (L.) Moench & quiabo & Rheumatism, sinusitis & $\mathrm{F}$ \\
\hline Acacia bahiensis Benth. & $\begin{array}{l}\text { espinheiro-vermelho, } \\
\text { espinheiro-branco }\end{array}$ & Colic, grippe & $\mathrm{F}$ \\
\hline Acanthospermum hispidum DC. & mau-vizinho, amarra-vizinho & Inflammation, cough & $\mathrm{F}$ \\
\hline Allium sativum $\mathrm{L}$. & alho & Fainting, grippe, dizziness, cough, tuberculosis & $\mathrm{F}$ \\
\hline Ananas sativus Schult. \& Schult. f. & abacaxi & Grippe, cough & $\mathrm{F}$ \\
\hline Arachis hypogaea $\mathrm{L}$. & amendoim & Aphrodisiac & $\mathrm{F}$ \\
\hline Beta vulgaris L. & beterraba & Anemia & $\mathrm{F}$ \\
\hline Bromelia laciniosa Mart. ex Schult. f. & macambira & Injury & M \\
\hline Calotropis procera (Aiton) W.T. Aiton & algodão-seda & Headache, wound & $\mathrm{F}$ \\
\hline Capparis jacobinae Moric. ex Eichler & inço & Toothache, cough & $\mathrm{F}$ \\
\hline Catharanthus roseus (L.) G. Don & bom-dia, boa-noite & Bleeding, insomnia, malaria & $\mathrm{F}$ \\
\hline Citrus limonia (L.) Osbeck & laranja-cravo & Heartburn, headache, cold, sickness & $\mathrm{F}$ \\
\hline Egletes viscosa (L.) Less. & macela & Heartburn, bad breath & $\mathrm{F}$ \\
\hline Eugenia uvalha Cambess. & ubaia & Bellyache & $\mathrm{F}$ \\
\hline Hibiscus rosa-sinensis L. & papoula & Toothache & $\mathrm{F}$ \\
\hline Lactuca sativa $\mathrm{L}$. & alface & High blood pressure & M \\
\hline Lantana camara L. & azedinho, chumbinho & Numbness of the mouth, cough & $\mathrm{F}$ \\
\hline Leucaena leucocephala (Lam.) de Wit & espinheiro & Cough & $\mathrm{F}$ \\
\hline Lycopersicon esculentum Mill. & tomate & Healing, swollen leg & $\mathrm{F}$ \\
\hline Manihot esculenta Crantz & mandioca & Bellyache and aphtha & $\mathrm{F}$ \\
\hline Matricaria chamomilla $\mathrm{L}$. & camomila & Congestion & $\mathrm{F}$ \\
\hline Musa paradisiaca $\mathrm{L}$. & bananeira & Bleeding, burning & $\mathrm{F}$ \\
\hline Opuntia ficus-indica (L.) Mill. & palma & Furuncle & $\mathrm{F}$ \\
\hline Passiflora edulis Sims & maracujá & Sedative, insomnia & $\mathrm{F}$ \\
\hline Persea americana Mill. & abacate & Kidney disorders, sedative & M \\
\hline Plumbago scandens L. & louco & Allergies, warts & M \\
\hline Sapium lanceolatum (Müll. Arg.) Huber & burra-leiteira & Injury & $\mathrm{F}$ \\
\hline Sechium edule (Jacq.) Sw. & chuchu & High pressure & M \\
\hline Senna spectabilis (DC.) H.S. Irwin \& Barneby & canafístula & Hemorrhoids & $\mathrm{F}$ \\
\hline Sesamum indicum $\mathrm{L}$. & gergelim & Stroke, insomnia & M \\
\hline Sida cordifolia $\mathrm{L}$. & malva-branca & Weakness & M \\
\hline Spondias mombin L. & cajá & Uterine inflammation & M \\
\hline Tabebuia caraiba (Mart.) Bureau & caibeira & Rheumatism & M \\
\hline Targetes erecta L. & cravo-branco & Shortness of breath & $\mathrm{F}$ \\
\hline Tillandsia usneoides (L.) L. & salambaia-comprida & Diabetes & M \\
\hline Vernonia condensata Backer & alcachofra & Bad digestion & M \\
\hline Vitis vinifera $\mathrm{L}$. & uva & Helminthiasis & $\mathrm{F}$ \\
\hline
\end{tabular}

F-Female/M-Male 
ethnospecies and therapeutic uses for the "farmer" and "non-farmer" categories, there were significant differences $(\mathrm{H}=8.49, p=0.0036$ and $\mathrm{H}=6.7, p=0.0096$ respectively). Perhaps this is an effect of the differences between the samples. Farmers seemed to be on average more knowledgeable about ethnospecies and their therapeutic indications (16.9 \pm 12.4 and $13.4 \pm 10.8$, respectively) than non-farmers $(12 \pm 9.6$ and $10.6 \pm 7.9)$.

The knowledge of the non-farmers may be influenced by the interaction of two factors: age and occupation. Most (19) non-farmers were between 18 and 28 years of age, while most (57) farmers ranged between 39 and 78 years of age. In this community, in addition to field observations and reports by some residents, it was observed that few young people were interested in working in agriculture. We observed that all young people (18-28) not working in agriculture were women and that these individuals were less knowledgeable about plants and their uses.

\section{Discussion}

\section{The influence of age on local knowledge}

The relationship between age and the number of plants cited for medical use was also observed in other studies (Voeks \& Leony, 2004; Almeida et al., 2010; Parveen et al., 2007). The greater knowledge of older people, as observed in this study, may be related to the degree of opportunity that they have had to learn about medicinal plants and their therapeutic uses; for older people, it appears, there is more experience and contact with these resources. Another relevant explanation may be related to the fact that these people are more susceptible to illness than young people, which again opens up a space for them to have closer contact with the world of medicinal plants in the region where they live. Similar data emerged in the work of Voeks \& Leony (2004), who studied the Lençóis community located in the state of Bahia in northeastern Brazil.

The knowledge of some young people may be related to their lack of interest in plant-based medicines, mainly because of their lack of credibility; some believe that allopathic medicine is more efficient than traditional medicine, as has also been found to be the case in rural communities in the Churu district in the Thar desert, India (Parveen et al., 2007). Concerning this issue, some residents reported that before health workers were present, there were many healers in the region; it is also said that after the arrival of doctors, many residents stopped using medicines made from plants. Matavele \& Habib (2000) found in their work in Cabo Delgado, Mozambique that younger people prefer to go to health centers to treat health problems more than older ones do.

Some authors suggest that the lack of knowledge amongst young people, which was evident in this study, may also be influenced by modernization (Caniago \& Siebert, 1998; Quinlan \& Quinlan, 2007). In some regions of Debre Libanos, Ethiopia, it was verified by Teklehaymanot et al. (2007) that young people are flock to the urban centers in search of employment and education and thus that the traditional knowledge of plants is concentrated in the few experts in the region. In the community studied, it has been reported by informants that in recent decades, many young people have migrated to urban centers in other states in search of employment. This trend is worrisome because such actions may affect the transfer of local medical practices between generations.

When the influence of age on different gender was analyzed, it was found that in general, there is informationsharing between the intermediate age groups both for women and for men; however, for men, this knowledge is more uniform in all age groups. This may be related to the fact that men have to work in agriculture very early in life and then can start the process of learning about plants in a practical way (through contact with the resource) and by splitting the work area early between men of different ages, which facilitates the creation of opportunities to share experiences.

The low level of knowledge on medicinal plants among younger women as compared to older women can be explained by their indifference regarding the use of this resource and also by their having little need for such knowledge as a result of their good health; this age group presents a relatively low number of diseases. Another explanation is that at this stage, women usually do not have children yet and thus are not accumulating knowledge regarding the treatment of diseases common in children.

Species common to all age groups (Table 2) present widespread use in areas of caatinga vegetation (Albuquerque et al., 2007) because most of them are native and have many diverse uses (Alencar, 2008). These various therapeutic applications can address problems with several bodily systems (for example, disorders of the digestive system and disorders of the respiratory system) and can be related to more frequent illnesses.

Even with increased knowledge about the ethnospecies and their therapeutic uses among older individuals, this does not imply in loss of knowledge because it is necessary to consider if the knowledge is being transmitted in the region. It is important to be attentive to this question because when knowledge about use of plants is restricted to a group, the risk of loss is much greater if transmission is interrupted (Albuquerque \& Andrade, 2002).

Gender influence on local knowledge 
Similar knowledge was also found among men and women in some studies, such as Almeida et al. (2010), Ayantunde et al. (2008) and Figueiredo et al. (1997). Monteiro et al. (2006b). When evaluating the distribution of knowledge about the use of "angico" (Anadenanthera colubrina (Vell.) Brenan, Fabaceae) in a rural community of the Agreste-Pernambuco, which is near the region where this study was performed, they reported that women cited more information on medicinal uses of this species than did men. As observed in this study, both genders disorders of the digestive system useful plants for curing diseases, with no clear division of knowledge among the genders. However, this does not mean that knowledge of men are similar for that of women (Ayantunde et al., 2008); indeed, it was of course observed that with regard to the plant repertoire and their uses, there was knowledge particular to each gender.

Some authors have shown that in most rural areas of Brazil, women have more specialized knowledge because they are often looked for to diagnose and treat certain types of diseases (Voeks \& Leony, 2004). Voeks (2007) notes that women from the Lençóis communityBahia proved more able to identify and name the plants and report on their therapeutic properties. Such knowledge is derived from experience caring for the health of their families, greater contact with agriculture and the management of gardens; there is a greater number of perennial species in these anthropogenic areas (Voeks, 2007). Teklehaymanot et al. (2007), studying the knowledge and use of medicinal plants in Ethiopia, reported that men are the most knowledgeable about plants. With a result similar to that found in the Dusun medicine, at Brunei Darussalam, there was a distinction between gender roles in the healing system. Women specialized in treating spiritual diseases, while men were experts at curing diseases related to organic disorders (Voeks \& Nyawa, 2001).

Currently in the Carão community, men are the main users of the slope areas in the region (secondary vegetation). However, there was a greater flow of both men and women around sixty years ago because there was more land under cultivation for subsistence (Almeida, 2008). Today, women spend most of their time on domestic activities along with agriculture or in some cases caring for livestock such as cows and goats. The occupations of and areas frequented by individuals can strongly affect the knowledge that they assimilate from the environment. Voeks (2007), for example, showed that women in the Lençóis community in Bahia obtained more medicinal plants from anthropogenic areas. Similarly, women in Kalimantan, Indonesia are more familiar with these areas due to the activities carried out near their residence, and in this way, they are different from men, who are themselves more knowledgeable about primary vegetation areas because of their hunting and resource extraction activities in the forest (Caniago \& Siebert, 1998).

For the Carão community, there is no clear-cut division of responsibilities. Regardless of gender, most people work in agriculture, although some divisions exist in the spaces used, as previously discussed in relation to visiting hilly areas. Voeks (2007) notes that when people are exposed to the same repertoire of plants, they can develop similar levels of understanding. As seen in the results, men and women seem to socially share the resources uses in the region, but it is important to emphasize that the approach in this study was built on the total number of ethnospecies and uses cited without checking in a background if there are similarities or differences in the knowledge.

In a study performed by Hanazaki et al. (2000) in an Atlantic forest area, the authors found that there were gender differences in knowledge related to the medical, food and technology categories. In one of the communities studied, the researchers found that women know about more food plants than men because agriculture is women's responsibility in that area. Men, in turn, had greater knowledge about medicinal plants and manufactured products because they worked more on acquiring resources from the forest.

\section{Influence of occupation type on local knowledge}

Occupation was a determining factor in the distribution of knowledge. Those who had greater contact with plant resources seem to be more knowledgeable about them. Activities that promote more significant removal of plant resources such as trade may jeopardize interest in using plants to cure diseases. However, it can not be disregarded that knowledge, in addition to be related to one's occupation, is also built through other means such as social interaction (Singhal, 2005). The lack of contact people have with vegetation may affect the transmission of knowledge about plants once people tend to disconnect themselves intellectually and spiritually from these resources (Voeks \& Leony, 2004). These people become more vulnerable to influences of the Western world and can still leave some practices connected to their culture, which in turn were acquired over years of contact with plant resources (Ohmagari \& Berkes, 1997). This loss of knowledge may be related to commercial occupancy, which can often lead people to leave the rural environment or even reduce their contact with plant resources (Quinlan \& Quinlan, 2007). The market economy may influence this relationship, as shown by Godoy et al. (2005), who observed that the market's influence on the knowledge of indigenous people leads 
to the erosion of knowledge about both plants and animals.

It is still necessary to study the influence of age, gender and occupation on the knowledge distribution for medicinal plants. The study of people's knowledge of medicinal plants can contribute information about the use of these plants by local people and also shed light on the patterns governing people-plant relationships. In addition, this information is important for projects that promote the sustainable use of natural resources, as it indicates who has greater knowledge of certain resources.

\section{Acknowledgments}

The authors are grateful to the Carão community in face of the receptive welcome, and the following researchers from the Laboratory of Applied Ethnobotany (LEA) for support in ethnobotanical data collection: Ernani Machado de Freitas Lins Neto, Nélson Leal Alencar, Thiago Sousa Araújo, Joabe Gomes de Melo, Alyson Luiz de Almeida, Miguel de Santana Almeida, Luciana Gomes de Sousa, Viviany Teixeira do Nascimento e Lucilene Lima dos Santos. To Victoria Lacerda, student of Federal University of Santa Catarina for field support during her training in the LEA. The City of Altinho, in the person of the Secretary of Agriculture, Mr. Miguel Andrade Jr., for the logistical support. The Health Workers from Carão Community, Mr. Inaldo and Mr. Alexandre, for the support. To CNPq for financial support and research productivity fellowship in offered to U.P. Albuquerque.

\section{References}

Albuquerque UP, Andrade LHC 2002. Conhecimento botânico tradicional e conservação em uma área de caatinga no estado de Pernambuco, nordeste do Brasil. Acta Bot Bras 16: 273-285.

Albuquerque UP, Andrade LHC, Silva ACO 2005. Use of plant resources in a seasonal dry forest (northeastern Brasil). Acta Bot Bras 19: 27-38.

Albuquerque UP, Medeiros PM, Almeida ALS, Monteiro JM, Lins-Neto EMF, Melo JG, Santos JP 2007. Medicinal plants of the caatinga (semi-arid) vegetation of NE Brazil: A quantitative approach. J Ethnopharmacol 114: 325-354.

Albuquerque UP, Lucena RFP, Alencar NL 2008. Métodos e técnicas para coleta de dados etnobotânicos. In: Albuquerque UP, Lucena, RFP, Cunha LVF (org.). Métodos e técnicas na pesquisa etnobotânica. 2. ed. Recife: NUPEEA, p. 48-50.

Alencar NL 2008. O papel das plantas exóticas em farmacopéias tradicionais. Recife, 44 p. Dissertação de Mestrado, Programa de Pós-graduação em Biologia
Vegetal, Universidade Federal de Pernambuco.

Alencar NL, Araújo TAS, Amorim ELC, Albuquerque UP 2009. Can the apparency hypothesis explain the selection of medicinal plants in an area of caatinga vegetation? A chemical perspective. Acta Bot Bras 23: 908-909.

Alencar NL, Araújo TAS, Amorim ELC, Albuquerque UP 2010. The inclusion and selection of medicinal plants in traditional pharmacopoeias evidence in support of the diversification hypothesis. Econ Bot 64: 68-79.

Almeida ALS 2008. Biologia reprodutiva de Spondias tuberosa Arruda, Anacardiaceae, sob diferentes condições de manejo em uma área de caatinga de Pernambuco. Recife, 30 p. Dissertação de Mestrado, Programa Pós-graduação em Botânica, Universidade Federal Rural de Pernambuco.

Almeida CFCBR, Ramos MA, Amorim ELC, Albuquerque UP 2010. A comparison of knowledge about medicinal plants for three rural communities in the semi-arid region of northeast of Brazil. J Ethnopharmacol 127: 674-684.

Araújo TAS, Alencar NL, Amorim ELC, Albuquerque UP 2008. A new approach to study medicinal plants with tannins and flavonoids contents from the local knowledge. J Ethnopharmacol 120: 72-80.

Ayantunde AA, Briejer M, Hiernaux P, Udo HMJ, Tabo R 2008. Botanical knowledge and its differentiation by age, gender and ethnicity in southwestern Níger. $J$ Hum Ecol 36: 881-889.

Ayres M, Ayres MJ, Ayres DL, Santos SA 2007. BioEstat 5.0: aplicações estatísticas nas áreas das ciências biológicas e médicas. Brasília: Sociedade Civil Mamirauá.

Bain JH 1993. Mexican rural women's knowledge of the environment. Mex Stud 9: 259-274.

Caniago I, Sibert SF 1998. Medicinal plant ecology, knowledge and conservation in Kalimantan, Indonésia. Econ Bot 52: 229-50.

Condepe/Fidem 2001. Agência Estadual de Planejamento e Pesquisas de Pernambuco, http:// www.condepefidem. pe.gov.br, Access Dec 2009.

Estomba D, Ladio A, Lozada M 2006. Medicinal wild plant knowledge and gathering patterns in a Mapuche community from north-western Patagonia. $J$ Ethnopharmacol 103: 109-119.

Figueiredo GM, Leitão-Filho HF, Begossi A 1993. Ethnobotany of atlantic forest coastal communities: diversity of plant uses in Gamboa (Itacuruçá Island, Brazil). J Hum Ecol 21: 419-430.

Figueiredo GM, Leitão-Filho HF, Begossi A 1997. Ethnobotany of atlantic forest coastal communities: II. Diversity of plant uses at Sepetiba bay (SE Brazil). J Hum Ecol 25: 353-360.

Godoy R, Reyes-García V, Byron E, Leonard WR, Vadez V 2005. The effect of market economies on the Well- 
Being of indigenous peoples and on their use of renewable natural resources. Annu Rev Anthropol 34: $121-138$.

Hanazaki N, Tamashiro JY, Leitão-Filho HF, Begossi A 2000. Diversity of plant uses in two Caiçara communities from the Atlantic forest coast, Brasil. Biodivers Conserv 9: 597-615.

ITEP/Lamepe 2007. http://www.itep.br/LAMEPE.asp, access October 2009.

Lins-neto EMF, Peroni N, Albuquerque UP 2010. Traditional knowledge and management of Spondias tuberosa Arruda (Umbu), Anacardiaceae, an endemic species from the semi-arid region of northeast Brazil. Econ Bot 64: 11-21.

Matavele J, Habib M 2000. Ethnobotany in Cabo Delgado, Mozambique: use of medicinal plants. Environ Dev Sustain 2: 227-234.

Monteiro JM, Albuquerque UP, Lins-Neto EMF, Araújo EL, Amorim ELC 2006a. Use patterns and knowledge of medicinal species among two rural communities in Brazil semi-arid northeastern region. J Ethnopharmacol 105: 173-186.

Monteiro JM, Almeida CFCBR, Albuquerque UP, Lucena RFP, Florentino ATNF, Oliveira RLC 2006b. Use and traditional management of Anadenanthera colubrina (Vell.) Brenan in the semi-arid region of northeastern Brazil. J Ethnobiol Ethnomed 2: 1-7.

Ohmagari K, Berkes F 1997. Transmission of indigenous knowledge and bush skills among the western James Bay Cree women of subarctic Canada. J Hum Ecol 25: 197-222.

Parveen BU, Roy S, Kumar A 2007. Traditional uses of medicinal plants among the rural communities of Churu district in the Thar Desert, India. J Ethnopharmacol 113: 387-399.

Quinlan MB, Quinlan RJ 2007. Modernization and medicinal plant knowledge in a caribbean horticultural village. Med Anthropol Q 21: 169-192.

Santos LL, Ramos MA, Silva SI, Sales MF, Albuquerque UP 2009. Caatinga ethnobotany: anthropogenic landscape modification and useful species in Brazil's semi-arid northeast. Econ Bot 63: 363-374.

Singhal R 2005. Medicinal plants and primary health care: the role of gender. $J$ Health Manag 7: 277-293.

Teklehaymanot T, Giday M, Medhin G, Mekonnen Y 2007. Knowledge and use of medicinal plants by people around Debre Libanos monastery in Ethiopia. $J$ Ethnophamacol 111: 271-283.

Voeks RA, Nyawa S 2001. Healing flora of the Brunei Dusun. Borneo Res Bull 32: 178-195.

Voeks RA, Leony A 2004. Forgetting the forest: assessing medicinal plant erosion in eastern Brazil. Econ Bot 58: S294-S306.

Voeks RA 2007. Are women reservoirs of traditional plant knowledge? Gender, ethnobotany and globalization in northeast Brazil. Singapore J Trop Geo 28: 7-20.

\section{*Correspondence}

Ulysses P. de Albuquerque

Departamento de Biologia, Área de Botânica, Laboratório de Etnobotânica Aplicada, Universidade Federal Rural de Pernambuco

Rua Dom Manoel de Medeiros s/n, Dois Irmãos, 52171-900

Recife-PE, Brazil

upa@db.ufrpe.br 